Original scientific paper - Izvorni znanstveni rad

UDK: 637.146 .21

\title{
An innovative approach: cow/oat milk based kefir
}

doi: 10.15567/mljekarstvo.2015.0304

\author{
Nayil Dinkçi ${ }^{1}$, Harun Kesenkaş ${ }^{*}$, Figen Korel ${ }^{2}$, Özer Kınık ${ }^{1}$ \\ ${ }^{1}$ Ege University Faculty of Agriculture Department of Dairy Technology, \\ 35100 Bornova, Izmir, Türkiye \\ ${ }^{2}$ Izmir Institute of Technology Faculty of Engineering Department of Food Engineering, \\ 35430 Urla, Izmir, Türkiye
}

Received - Prispjelo: 23.06.2014.

Accepted - Prihvaćeno: 01.06.2015.

\begin{abstract}
The aim of this study was to evaluate the potential of kefir production using cow-oat milk mixture. Therefore kefir samples with 20, 40 and $60 \%$ of oat milk were produced. The effect of oat-milk ratio on physicochemical, rheological, microbiological and sensory characteristics of the kefir samples was studied during 21 days storage at refrigerated conditions. Increasing oat milk concentration affected the whey-off and apparent viscosity by higher whey off and lower viscosity results. Also the proteolytic activity of the samples was decreased by raising the oat milk concentrations. Increase of the oat milk concentration leaded to a decrease of $\mathrm{pH}$ of the samples. Statistical analysis showed that the lactococci and lactobacilli viable cell counts differed among the samples while the highest count was detected in sample with the highest amount of oat milk. The control sample (without oat milk) had higher yeast count during the storage period. The final product with $20 \%$ of oat-milk and without addition of flavour was found to be the most acceptable by the sensory panellists. The results indicate the possibility for a new cow/oat milk based kefir.
\end{abstract}

Key words: kefir, oat milk, sensory analysis, rheology, microbiology

\section{Introduction}

Since the late twentieth century, modern life forced the over-use of refined food products as well as the preference to foods of animal origin. Along with high stress factors and awareness of the relationship between diet and health, there is a growing consumers' demand for a new generation of food products - the "functional foods" (Bekers et al., 2001; Cirak, 2009). Designer foods, pharma-foods, medicinal foods, nutraceuticals, therapeutic foods, super foods, foodiceuticals, and medi-foods are all known as functional foods (Soccol et al., 2010). Generally, functional foods contain some health promoting components along with basic nutrients (Karagül-Yüceer and Avşar, 2009). Several components of food are known to be particularly beneficial to human health such as the probiotic bacteria, dietary fibers, polyunsaturated fatty acids, oligosaccharides, minerals and antioxidants (Bekers et al., 2001; Jelicic et al., 2008).

Many researchers have recognized the beneficial effects of consuming oat and oat based food products. Oat has been reported to be effective in moderating the effects of hypertension, lowering the total serum- and LDL-cholesterol, regulating blood glucose and insulin levels, controlling weight and promoting gastrointestinal health. Many of these effects were attributed to the presence of dietary fibers, principally the $\beta$-glucans (Bekers et al., 2001; Lambo et al., 2005).

Kefir is a soured, frothy and mildly alcoholic dairy drink produced by the combination of acid and alcohol fermentation. For many years it was produced and used in Middle Asian and Eastern European countries, Russia and Caucasia for many years. Microbiological and chemical composition of 
kefir provides a complex probiotic effect due to the inherent lactic acid bacteria and yeasts (Kesenkas et al., 2011a; Pogacic et al., 2013). Lactobacilli are present as the largest portion of this microbial population with lactococci, acetic acid bacteria and yeasts making up the remaining part of the microorganisms contained in kefir (Kesenkaş et al., $2011 \mathrm{~b})$. Although the research results on the probiotic properties of kefir microflora are limited in comparison to milks fermented with classical probiotic bacteria (Stepaniak and Fetlinski, 2002), kefir has functional properties including reduction of lactose intolerance symptoms, stimulation of the immune system, hypocholesteremic, antimutagenic and anticarcinogenic properties (Guzel-Seydim et al., 2011) .

The use of oat in functional foods is receiving increased attention. Some recent studies have shown that oat is a suitable substrate for various kinds of lactic acid bacteria and functionality of fermented products, mainly yogurts, could be improved by production of oat-based milk or cow-oat milk mixtures (Fernandez-Garcia et al., 1998; Bekers et al., 2001; Martensson et al., 2001). There is no reported research on the properties of cow/oat milk based kefir produced from grains. So the aim of this study was to investigate the potential for production of kefir using cow-oat milk mixtures in various ratios $(80: 20,60: 40,40: 60)$. In order to determine the effects of the oat-milk ratio on some physical, chemical, microbiological and sensory properties of the produced kefir samples, the analyses were conducted during 21 day long storage period.

\section{Materials and methods}

\section{Production of kefir samples}

The rolled oats (Hahne, Germany) were floured and then used to prepare oat milk with a concentration of $13 \mathrm{~g}$ in $100 \mathrm{~mL}$ water. Whole fat cow milk and oat milk mixtures in 4 different ratios were used for kefir production (100\% cow milk (K), $80 \%$ cow milk - $20 \%$ oat milk (A), $60 \%$ cow milk - $40 \%$ oat milk (B) and $40 \%$ cow milk - $60 \%$ oat milk (C)). Samples were pasteurized for $10 \mathrm{~min}$ at $90^{\circ} \mathrm{C}$, immediately cooled down to $25^{\circ} \mathrm{C}$ and inoculated with $3 \%(\mathrm{~g} / \mathrm{mL})$ kefir grains (Ege University Dept. of Dairy Technology, Turkey). The samples were incubated at $25^{\circ} \mathrm{C}$ until $\mathrm{pH}$ 4.55-4.60 without stir- ring about $20 \mathrm{~h}$. The grains were separated from the fermented milk mixtures by filtering them through a sieve. Samples were taken into $250 \mathrm{~mL}$ glass bottles and stored at $4 \pm 1{ }^{\circ} \mathrm{C}$ for 21 days. Physicochemical, microbiological and sensorial tests were performed on the $1^{\text {st }}, 7^{\text {th }}, 14^{\text {th }}$ and $21^{\text {st }}$ days of storage.

\section{Physicochemical analysis}

The $\mathrm{pH}$ value was determined by a $\mathrm{pH}$ meter (Hanna Instruments 211, Germany). The titratable acidity, contents of total solids and fat contents were measured by the Soxhlet-Henkel method, drying at $105{ }^{\circ} \mathrm{C}$ until constant mass and Gerber method respectively, according to AOAC (2000), Renner (1993) and Oysun (2001). The protein content was determined by Kjeldahl method using a Gerhardt Turbotherm digestion system and distillation unit Gerhardt Vapodest (Germany). A multiplication factor 6.38 was used to convert the percentage of the nitrogen to the percentage of the protein. The proteolysis in the samples was determined by measuring liberated amino acids and peptides using the O-phtaldialdehyde (OPA) method as described by Donkor et al. (2007). The proteolytic activity of the samples was expressed as the amount of $\alpha$-amino groups measured as difference in absorbance values.

\section{Rheological analysis}

In order to monitor the stability against sedimentation (whey-off), $100 \mathrm{~mL}$ of the samples were added to measuring cylinders $(100 \mathrm{~mL})$ and stored at $4{ }^{\circ} \mathrm{C}$. On each analyse date, the serum layer was monitored visually and the whey-off values (\%) were calculated according to Paraskevopolou et al. (2003).

The apparent viscosity of the samples was measured with a rotational Brookfield DV-II+Pro viscometer (Middlebro, MA, USA). All viscosity measurements were carried out with the LV2 spindle at a spindle rotation of $10.00 \mathrm{rpm}$ and temperature of the samples was $10^{\circ} \mathrm{C}$. The data were evaluated using Rheocalc V3.2 Build 46-1 (Brookfield Engineering Labs).

\section{Sensory characteristics}

The sensory evaluation of the test samples was carried out by 8 experienced panellists from Department of Dairy Technology who were familiar with kefir. The kefir samples were organoleptically 
examined for taste, odour, consistency and overall acceptability. The panellists rated the samples on the basis of the nine point's hedonic scale (Bodyfelt at al., 1988). The sensory scores stated; Dislike extremely $=1$, Dislike very much $=2$, Dislike moderately $=3$, Dislike slightly $=4$, Neither like nor dislike $=5$, Like slightly $=6$, Like moderately $=7$, Like very much $=8$, Like extremely $=9$. The samples were coded with three digit random numbers and served to the panellists randomly. Water, plain crackers and bread were served to the panellists for rinsing between samples.

\section{Microbiological analysis}

The samples for microbiological analyses were taken in aseptic conditions on every analysed date. A quantity of $10 \mathrm{~g}$ from each sample was emulsified in $90 \mathrm{~mL}$ of sterile $2 \%$ (w/v) tri-sodium citrate solution in a laboratory blender (Colworth Stomacher 400, Seward, UK). Subsequently serial dilutions were made with Ringers' solution. The enumeration of microorganisms was carried out using the methods described by Irigoyen et al. (2005). Lactococci count was carried out on M17 medium (pH $7.2 \pm 0.2)$ at an incubation temperature of $30^{\circ} \mathrm{C}$ under aerobic conditions for 2 days. Lactobacilli count was performed on MRS medium $(\mathrm{pH} 6.5 \pm 0.2)$ at an incubation temperature of $30^{\circ} \mathrm{C}$ under anaerobic conditions for 3 days. Cycloheximide $(200 \mathrm{mg} / \mathrm{L})$ was added to the two above media to inhibit yeast growth. Yeasts were grown on OGYE medium $(\mathrm{pH}$ $7.0 \pm 0.2$ ) added with $1 \%$ oxytetracycline at $25^{\circ} \mathrm{C}$ for 5 days.

\section{Statistical analysis}

The effect of oat-milk ratio on some physical, chemical, microbiological and sensory properties of the produced kefir samples was carried out by Analysis of Variance (ANOVA) and the mean differences were analysed using Duncan's Multiple Range Test when a $0.05 \%$ difference in the level of these values was verified. Also the effect of storage on the samples was determined by the same method using SPSS ${ }^{\odot} 15.0$ for Windows. All experiments were conducted in triplicate.

\section{Results and discussion}

\section{Chemical properties and composition}

Table 1 presents the results for composition as total solids, fat and protein contents of kefir samples. The data showed that fat and protein contents were affected by the cow/oat milk ratios used in the production. The total solids content of kefir samples with 20, 40 and $60 \%$ of oat milk decreased slightly. The protein content ranged between $1.53 \%$ and $3.48 \%$. These differences could be due to different ratios of oat milk added into cow milk. Other researches with plain kefir had different results. Irigoyen et al. (2005) produced kefir samples using $1 \%$ and $5 \%$ kefir grains and obtained thereby the fat and total solids contents of 3.20-3.59\% and 11.3$11.6 \%$ respectively. Dinç (2008) demonstrated the mean values of $2.7 \%$ and $13.3 \%$ for fat and total solid contents respectively. Moreover, Muir et al. (1999) reported the protein content of traditional kefir samples between 3.22 and $4.54 \%$.

Table 1. Chemical composition of kefir samples $(\mathrm{n}=3, \pm \mathrm{SD})$

\begin{tabular}{cccc}
\hline Samples & Total solids, \% & Fat, \% & Protein, \% \\
\hline A & $10.99 \pm 0.10^{\mathrm{b}}$ & $2.50 \pm 0.00^{\mathrm{c}}$ & $2.78 \pm 0.00^{\mathrm{c}}$ \\
\hline B & $10.94 \pm 0.04^{\mathrm{b}}$ & $2.05 \pm 0.00^{\mathrm{b}}$ & $2.15 \pm 0.02^{\mathrm{b}}$ \\
\hline C & $10.76 \pm 0.01^{\mathrm{a}}$ & $1.50 \pm 0.00^{\mathrm{a}}$ & $1.53 \pm 0.10^{\mathrm{a}}$ \\
\hline K & $11.02 \pm 0.04^{\mathrm{b}}$ & $2.83 \pm 0.10^{\mathrm{d}}$ & $3.48 \pm 0.02^{\mathrm{d}}$ \\
\hline
\end{tabular}

a, b, c, dMeans in the same column with different superscripts significantly differ $(\mathrm{P}<0.05)$. A: $80 \%$ cow milk- $20 \%$ oat milk kefir; B: $60 \%$ cow milk- $40 \%$ oat milk kefir; C: $40 \%$ cow milk- $60 \%$ oat milk kefir; K: Control sample (100\% cow milk kefir), SD: Standard deviation

\section{Acidity}

Table 2 shows $\mathrm{pH}$ value and titratable acidity of kefir samples produced from cow milk and cow/ oat milk blends. The average $\mathrm{pH}$ values at the $1^{\text {st }}$ day of storage were in the range between 4.31 and 4.55. The $\mathrm{pH}$ of sample $\mathrm{A}$ was higher than the $\mathrm{pH}$ of the other samples, whereas the sample $\mathrm{C}$ had the lowest $\mathrm{pH}$ values at all storage periods $(\mathrm{P}<0.05)$. It could be concluded that the increase of oat milk concentration in kefir samples resulted in a decrease of the $\mathrm{pH}$ value. 
Some previous studies suggested no significant differences in $\mathrm{pH}$ changes during the storage period (Irigoyen et al. 2005; Tratnik et al., 2006). However, it was reported that $\mathrm{pH}$ decreased significantly during the first day or week of storage depending on several factors such as the milk species, starter culture type, incubation time and temperature (Ertekin and Seydim, 2010; Öner et al., 2010; Gronnevik et al., 2011; Purnomo and Muslimin, 2012).

Lactic acid is extremely important for producing high-quality fermented milk products, and appropriate concentrations are needed to ensure proper flavour. According to the Turkish Codex, Standard for Fermented Milks (2001), the minimum titratable acidity has to be $0.60 \%$. According to the presented results, already at the first day after the production, the concentration of lactic acid in kefir samples was significantly different. The kefir sample with the highest amount of oat milk had the lowest lactic acid concentration, while the control sample containing cow milk solely had the highest amount. No significant differences were observed during storage $(\mathrm{P}>0.05)$. However the lactic acid concentrations in all samples, except the sample with the highest oat milk concentration, were found to be acceptable according to the Turkish Codex. One of the main reasons of lower acidity of cow/oat based kefir samples compared to cow milk kefir might be their lower buffering capacity (Martensson et al. 2000).

Table 2. Acidity of kefir samples during storage for 21 days $(n=3, \pm S D)$

\begin{tabular}{cccccc}
\hline & Samples & Day l & Day 7 & Day 14 & Day 21 \\
\hline & A & $4.55 \pm 0.01^{\mathrm{dZ}}$ & $4.27 \pm 0.00^{\mathrm{dX}}$ & $4.27 \pm 0.00^{\mathrm{cX}}$ & $4.35 \pm 0.02^{\mathrm{cY}}$ \\
\cline { 2 - 5 } $\mathrm{pH}$ & $\mathrm{B}$ & $4.42 \pm 0.01^{\mathrm{bZ}}$ & $4.18 \pm 0.00^{\mathrm{bX}}$ & $4.19 \pm 0.02^{\mathrm{bX}}$ & $4.30 \pm 0.00^{\mathrm{bY}}$ \\
\cline { 2 - 5 } & $\mathrm{C}$ & $4.31 \pm 0.00^{\mathrm{aW}}$ & $4.09 \pm 0.00^{\mathrm{aX}}$ & $4.11 \pm 0.01^{\mathrm{aY}}$ & $4.20 \pm 0.00^{\mathrm{aZ}}$ \\
\cline { 2 - 5 } & $\mathrm{K}$ & $4.48 \pm 0.00^{\mathrm{cZ}}$ & $4.21 \pm 0.00^{\mathrm{cX}}$ & $4.20 \pm 0.01^{\mathrm{bX}}$ & $4.28 \pm 0.00^{\mathrm{bY}}$ \\
\hline \multirow{2}{*}{$\begin{array}{c}\text { Titratable } \\
\text { acidity, \% }\end{array}$} & $\mathrm{A}$ & $0.70 \pm 0.00^{\mathrm{cXY}}$ & $0.68 \pm 0.01^{\mathrm{cX}}$ & $0.72 \pm 0.01^{\mathrm{cY}}$ & $0.73 \pm 0.00^{\mathrm{cY}}$ \\
\cline { 2 - 5 } & $\mathrm{B}$ & $0.60 \pm 0.02^{\mathrm{bX}}$ & $0.59 \pm 0.01^{\mathrm{bX}}$ & $0.62 \pm 0.01^{\mathrm{bX}}$ & $0.62 \pm 0.00^{\mathrm{bX}}$ \\
\cline { 2 - 5 } & $\mathrm{C}$ & $0.47 \pm 0.00^{\mathrm{aX}}$ & $0.47 \pm 0.00^{\mathrm{aX}}$ & $0.48 \pm 0.02^{\mathrm{aX}}$ & $0.48 \pm 0.00^{\mathrm{aX}}$ \\
\hline
\end{tabular}

$\mathrm{a}, \mathrm{b}, \mathrm{c}, \mathrm{d}$ Means in the same column with different superscripts significantly differ $(\mathrm{P}<0.05)$

$\mathrm{X}, \mathrm{Y}, \mathrm{Z}, \mathrm{W}$ Means in the same row with different superscripts among kefir samples significantly differ $(\mathrm{P}<0.05)$

SD: Standard deviation

A: $80 \%$ cow milk- $20 \%$ oat milk kefir; B: $60 \%$ cow milk- $40 \%$ oat milk kefir; C: $40 \%$ cow milk- 60 \% oat milk kefir; K: Control sample (100\% cow milk kefir)

Table 3. Whey-off values of kefir samples during storage for 2 ldays $(n=3, \pm S D)$

\begin{tabular}{cccccc}
\hline & Samples & Day l & Day 7 & Day 14 & Day 21 \\
\hline & A & $23.00 \pm 2.83^{\mathrm{aX}}$ & $30.25 \pm 1.77^{\mathrm{aXY}}$ & $33.75 \pm 1.77^{\mathrm{aY}}$ & $33.75 \pm 3.89^{\mathrm{aY}}$ \\
\cline { 2 - 5 } $\begin{array}{c}\text { Whey off } \\
\mathrm{mL} / 100 \mathrm{~mL}\end{array}$ & $\mathrm{~B}$ & $36.50 \pm 0.71^{\mathrm{cX}}$ & $42.00 \pm 1.41^{\mathrm{bY}}$ & $43.75 \pm 1.41^{\mathrm{bY}}$ & $43.50 \pm 1.41^{\mathrm{bY}}$ \\
\cline { 2 - 5 } & $\mathrm{C}$ & $22.00 \pm 0.71^{\mathrm{aX}}$ & $44.00 \pm 2.21^{\mathrm{bY}}$ & $44.25 \pm 2.12^{\mathrm{bY}}$ & $44.00 \pm 1.41^{\mathrm{bY}}$ \\
\cline { 2 - 5 } & $\mathrm{K}$ & $28.75 \pm 1.77^{\mathrm{bX}}$ & $35.50 \pm 3.54^{\mathrm{aX}}$ & $33.25 \pm 2.48^{\mathrm{aX}}$ & $32.50 \pm 0.00^{\mathrm{aX}}$ \\
\hline
\end{tabular}

$\mathrm{a}, \mathrm{b}, \mathrm{c}, \mathrm{d}$ Means in the same column with different superscripts significantly differ $(\mathrm{P}<0.05)$

$\mathrm{X}, \mathrm{Y}, \mathrm{Z}$ Means in the same row with different superscripts among kefir samples significantly differ $(\mathrm{P}<0.05)$

SD: Standard deviation of means

A: $80 \%$ cow milk- $20 \%$ oat milk kefir; B: $60 \%$ cow milk- $40 \%$ oat milk kefir; C: $40 \%$ cow milk- 60 \% oat milk kefir; K: Control sample (100\% cow milk kefir) 


\section{Whey-off}

Whey-off results of kefir samples were given in Table 3. The obtained results ranged from 22 to $44.25 \mathrm{~mL} / 100 \mathrm{~mL}$ during storage. Differences among the samples at the same storage period were significant $(\mathrm{P}<0.05)$. However, Duncan grouping showed that initially samples $A$ and $C$ had close values whereas sample $A$ and $K$ and, sample $B$ and $C$ had statistically similar results to each other at the rest of the storage period. Generally, values sharply increased in the first 7 days of storage for all samples and the storage period significantly affected whey off values except for the control sample $(\mathrm{P}<0.05)$. Surprisingly, sample C which contained the highest oat milk (60\%) concentration, had the lowest whey-off values at the first day of storage. such data could be attributed to the $\beta$-glucan found in oat milk which might have caused a decrease in whey-off. However, the observed increase during the rest of a storage period could have occurred as a result of the thermodynamic incompatibility between milk proteins and polysaccharides present in oat milk (Mejri and Sahli, 2014). Thus considering the whole storage period it appeared that addition of oat milk in concentrations above $20 \%$ negatively affected the whey-off values of the kefir samples.

\section{Apparent viscosity}

Table 4 presents the apparent viscosity values throughout the storage period. Flow properties of kefir samples made from cow's milk blended with different ratios of oat milk were similar. The shearthinning behaviour was expected in fermented milks because the textures of these products are affected by weak physical bonds, electrostatic and hydrophobic interactions (Ertekin and Seydim,
2010). Table 4 contains results related to the apparent viscosity changes ( $\mathrm{mPa}$ s) recorded at a share rate of $300 \mathrm{~s}^{-1}$ during the storage period. The highest viscosity was observed in sample $\mathrm{K}$ besides, while the lowest viscosity was determined in sample B.

Apparent viscosity changes of sample B exposed no significant differences during storage $(\mathrm{P}>0.05)$. However significant differences $(\mathrm{P}<0.05)$ were determined during storage of samples $\mathrm{A}, \mathrm{C}$ and $\mathrm{K}$. Viscosity of samples A and C decreased until the $14^{\text {th }}$ day of storage, whereas viscosity of samples $\mathrm{K}$ and $\mathrm{C}$ decreased until the $7^{\text {th }}$ day of storage. All samples reached their highest viscosity values at the beginning of storage. Obviously, the apparent viscosity values of the samples were affected by the oat milk concentrations. Increase of oat milk content in cow/ oat milk kefir negatively influenced its viscosity.

Garrote et al. (2001) reported that the apparent viscosity of different kefir samples (measured at shear rate $629 \mathrm{~s}^{-1}$ ) prepared with different kefir grains ranged between 7.5 and $15.4 \mathrm{mPa}$.s. Ertekin and Seydim (2010) stated that apparent viscosity in kefir containing different type of fat replacers varied from 1.83 to 3.12 Pa.s at $1^{\text {st }}$ day of storage or 1.83 to 3.75 Pa.s at $7^{\text {th }}$ day of storage. Also, it was reported that viscosity of cow milk kefir decreased to approximately $158 \mathrm{~s}^{-1}$ during the $1^{\text {st }}, 5^{\text {th }}$ and $10^{\text {th }}$ day of storage (Tratnik et al., 2006).

\section{Proteolysis}

The OPA based spectrophotometric assay detects released $\alpha$ amino groups, which orginate from the proteolysis of milk proteins, thus giving a direct measurement of proteolytic activity. Table 5 presents the proteolytic activity of the produced samples and

Table 4. Viscosity of kefir samples during storage for 21 days $(n=3, \pm S D)$

\begin{tabular}{cccccc}
\hline & Samples & Day l & Day 7 & Day 14 & Day 21 \\
\hline & A & $141.25 \pm 0.26^{\mathrm{bW}}$ & $110.58 \pm 1.13^{\mathrm{bY}}$ & $103.63 \pm 1.20^{\mathrm{cX}}$ & $123.53 \pm 4.60^{\mathrm{bZ}}$ \\
\cline { 2 - 5 } $\begin{array}{c}\text { Viscosity } \\
\text { mPa.s }\end{array}$ & $\mathrm{B}$ & $28.29 \pm 2.55^{\mathrm{aX}}$ & $20.95 \pm 0.07^{\mathrm{aX}}$ & $24.30 \pm 0.42^{\mathrm{aX}}$ & $24.40 \pm 2.40^{\mathrm{aX}}$ \\
\cline { 2 - 5 } & $\mathrm{C}$ & $50.39 \pm 4.38^{\mathrm{aY}}$ & $38.79 \pm 2.40^{\mathrm{aX}}$ & $38.54 \pm 13.4^{\mathrm{bX}}$ & $39.24 \pm 1.20^{\mathrm{aX}}$ \\
\cline { 2 - 5 } & $\mathrm{K}$ & $501.29 \pm 15.55^{\mathrm{cY}}$ & $402.42 \pm 34.92^{\mathrm{cX}}$ & $416.31 \pm 17.96^{\mathrm{dX}}$ & $438.36 \pm 22.41^{\mathrm{cXY}}$ \\
\hline
\end{tabular}

a, b, c, dMeans in the same column with different superscripts significantly differ $(\mathrm{P}<0.05)$

$\mathrm{X}, \mathrm{Y}, \mathrm{Z}$ Means in the same row with different superscripts among kefir samples significantly differ $(\mathrm{P}<0.05)$

SD: Standard deviation of means

A: $80 \%$ cow milk- $20 \%$ oat milk kefir; B: $60 \%$ cow milk- $40 \%$ oat milk kefir; C: $40 \%$ cow milk- 60 \% oat milk kefir; K: Control sample (100\% cow milk kefir) 
Table 5. Proteolytic activity in kefir samples during storage for 21 days $(n=3, \pm S D)$

\begin{tabular}{cccccc}
\hline & Samples & Day l & Day 7 & Day 14 & Day 21 \\
\hline & $\mathrm{A}$ & $0.346 \pm 0.000^{\mathrm{cX}}$ & $0.506 \pm 0.007^{\mathrm{cY}}$ & $0.522 \pm 0.012^{\mathrm{cY}}$ & $0.555 \pm 0.000^{\mathrm{cZ}}$ \\
\cline { 2 - 6 } $\begin{array}{c}\text { Proteolysis } \\
\text { (absorbance) }\end{array}$ & $\mathrm{B}$ & $0.296 \pm 0.001^{\mathrm{bX}}$ & $0.421 \pm 0.010^{\mathrm{bY}}$ & $0.429 \pm 0.001^{\mathrm{bY}}$ & $0.452 \pm 0.007^{\mathrm{bZ}}$ \\
\cline { 2 - 6 } & $\mathrm{C}$ & $0.249 \pm 0.003^{\mathrm{aX}}$ & $0.335 \pm 0.008^{\mathrm{aY}}$ & $0.342 \pm 0.002^{\mathrm{aY}}$ & $0.367 \pm 0.004^{\mathrm{aZ}}$ \\
\cline { 2 - 6 } & $\mathrm{K}$ & $0.427 \pm 0.021^{\mathrm{dX}}$ & $0.547 \pm 0.005^{\mathrm{dY}}$ & $0.571 \pm 0.020^{\mathrm{dY}}$ & $0.644 \pm 0.008^{\mathrm{dZ}}$ \\
\hline
\end{tabular}

$\mathrm{a}, \mathrm{b}, \mathrm{c}, \mathrm{d}$ Means in the same column with different superscripts significantly differ $(\mathrm{P}<0.05)$

$\mathrm{X}, \mathrm{Y}, \mathrm{Z}$ Means in the same row with different superscripts among kefir samples significantly differ $(\mathrm{P}<0.05)$

SD: Standard deviation of means

A: $80 \%$ cow milk - $20 \%$ oat milk kefir; B: $60 \%$ cow milk - $40 \%$ oat milk kefir; C: $40 \%$ cow milk - 60 \% oat milk kefir; K: Control sample (100\% cow milk kefir)

is expressed as the amount of free amino groups measured as absorbance values at $340 \mathrm{~nm}$.

The statistical analysis showed that the storage period significantly affected the amount of liberated amino acids in all kefir samples $(\mathrm{K}, \mathrm{A}, \mathrm{B}, \mathrm{C})$ $(\mathrm{P}<0.05)$ with the maximum absorbance values of $0.644,0.555,0.452$ and 0.367 respectively measured at $21^{\text {st }}$ day. The proteolysis in the control sample was significantly $(\mathrm{P}<0.05)$ higher than that of kefirs containing oat milks which could be clearly attributed to higher protein content as presented in Table 1. However, clearly appreciable proteolytic activity was observed in all kefir samples which explains the high cell density of lactic acid bacteria being dependent on a proteolytic system that can liberate essential amino acids from milk derived peptides (Donkor et al., 2007; Kesenkaş, 2011b).

\section{Sensory characteristics}

The sensory results of kefir samples are presented in Table 6. Taste was evaluated as the most important factor in the sensory analysis. The effect of storage period on taste scores was insignificant $(\mathrm{P}>0.05)$. Oat milk left a cereal taste in mouth. Increase of oat milk concentration over $20 \%$ had an adverse impact on taste scores $(\mathrm{P}<0.05)$. These scores slightly decreased at the $14^{\text {th }}$ day of storage and increased again at the end of storage. During this period the most noted defect was a yeasty, cereal taste and flavour. However, the scores were very close to each other at the end of storage $(\mathrm{P}>0.05)$.

Odour profiles of the samples scored from 4.96 to 8.09 at the first day (table 6). The control sample had highest odour scores at all storage periods. Intense souring, smell of oat milk and inadequate aroma affected the odour characteristics of sample C. As presented in table 6, there were significant differences among samples except on the $21^{\text {st }}$ day of storage $(\mathrm{P}<0.05)$. Moreover, the statistical analysis showed that storage period significantly affected the odour scores only in kefir containing $40 \%$ oat milk $(\mathrm{P}<0.05)$.

According to the obtained results, the essential factor affecting the consistency was oat milk used in kefir production. Consistency scores changed from 4.92 to 7.88 . The differences between samples were significant at all storage periods with control sample having the highest scores again $(\mathrm{P}<0.05)$. The consistency scores of samples $\mathrm{B}$ and $\mathrm{C}$ increased throughout the storage, where sample A showed a slight decrease on the $14^{\text {th }}$ day of storage. Also, the consistency scores of control sample decreased during storage. Nevertheless, the storage period effected only the consistency scores of sample B $(\mathrm{P}<0.05)$.

It appears that oat milk ratio in kefir samples significantly affected the overall acceptability $(\mathrm{P}<0.05)$. Similarly to other sensory characteristics, control sample had the highest overall acceptability scores while sample $\mathrm{C}$ had the lowest score. The results showed that taste and consistency were the most important parameters for the overall acceptability.

K1liç et al. (1999) reported that sensory scores for all kefir characteristics decreased significantly with time. In contrast to result of the present study, Irigoyen et al. (2005) stated that kefir samples revealed the best acceptability level in the first days of storage. The sensory character of fermented milk products like kefir was mainly influenced by the type of milk and starter culture used and storage period (Wszloek et al., 2001). 
Table 6. Sensory properties of kefir samples during the storage for 21 days $(n=3, \pm S D)$

\begin{tabular}{|c|c|c|c|c|c|}
\hline & Samples & Day 1 & Day 7 & Day 14 & Day 21 \\
\hline \multirow{4}{*}{ Taste } & A & $5.83 \pm 0.00^{c X}$ & $6.79 \pm 0.30^{c X}$ & $6.01 \pm 0.18^{c x}$ & $6.54 \pm 0.41^{\mathrm{aX}}$ \\
\hline & $\mathrm{B}$ & $5.00 \pm 0.00^{\mathrm{bX}}$ & $5.65 \pm 0.50^{\mathrm{bX}}$ & $5.01 \pm 0.18^{\mathrm{bX}}$ & $5.46 \pm 0.18^{\mathrm{aX}}$ \\
\hline & $\mathrm{C}$ & $4.55 \pm 0.18^{\mathrm{aX}}$ & $4.43 \pm 0.40^{\mathrm{aX}}$ & $3.94 \pm 0.08^{\mathrm{aX}}$ & $4.67 \pm 0.12^{\mathrm{aX}}$ \\
\hline & $\mathrm{K}$ & $8.09 \pm 0.12^{\mathrm{dX}}$ & $7.79 \pm 0.11^{\mathrm{dX}}$ & $6.82 \pm 0.26^{\mathrm{dX}}$ & $7.21 \pm 0.88^{\mathrm{ax}}$ \\
\hline \multirow{4}{*}{ Odour } & A & $6.92 \pm 0.59^{\mathrm{bx}}$ & $7.22 \pm 0.30^{c x}$ & $6.94 \pm 0.08^{\mathrm{cx}}$ & $6.88 \pm 0.18^{\mathrm{aX}}$ \\
\hline & $\mathrm{B}$ & $5.67 \pm 0.00^{\mathrm{ax}}$ & $6.43 \pm 0.20^{\mathrm{bY}}$ & $5.75 \pm 0.00^{\mathrm{bx}}$ & $6.30 \pm 0.18^{Y}$ \\
\hline & $\mathrm{C}$ & $4.96 \pm 0.30^{\mathrm{ax}}$ & $5.57 \pm 0.20^{\mathrm{ax}}$ & $4.82 \pm 0.09^{\mathrm{aX}}$ & $6.04 \pm 0.76^{\mathrm{ax}}$ \\
\hline & $\mathrm{K}$ & $8.09 \pm 0.12^{\mathrm{cX}}$ & $7.86 \pm 0.21^{c x}$ & $7.19 \pm 0.44^{c x}$ & $7.25 \pm 0.35^{\mathrm{ax}}$ \\
\hline \multirow{4}{*}{ Consistency } & A & $6.38 \pm 0.42^{\mathrm{bX}}$ & $7.11 \pm 0.05^{\mathrm{cX}}$ & $6.94 \pm 0.27^{c x}$ & $7.13 \pm 0.53^{\mathrm{bcx}}$ \\
\hline & B & $5.42 \pm 0.12^{\mathrm{aX}}$ & $5.93 \pm 0.10^{\mathrm{bY}}$ & $6.07 \pm 0.09^{\mathrm{bY}}$ & $6.17 \pm 0.23^{\mathrm{abY}}$ \\
\hline & $\mathrm{C}$ & $4.92 \pm 0.12^{\mathrm{aX}}$ & $5.00 \pm 0.20^{\mathrm{aX}}$ & $5.44 \pm 0.27^{\mathrm{aX}}$ & $5.46 \pm 0.18^{\mathrm{aX}}$ \\
\hline & $\mathrm{K}$ & $7.88 \pm 0.06^{\mathrm{cX}}$ & $7.65 \pm 0.30^{\mathrm{dx}}$ & $7.50 \pm 0.00^{\mathrm{dx}}$ & $7.42 \pm 0.35^{\mathrm{cX}}$ \\
\hline \multirow{4}{*}{$\begin{array}{c}\text { Overall } \\
\text { Acceptability }\end{array}$} & $\mathrm{A}$ & $6.13 \pm 0.42^{\mathrm{bx}}$ & $6.93 \pm 0.30^{\mathrm{cx}}$ & $6.41 \pm 0.13^{c x}$ & $6.92 \pm 0.35^{\mathrm{bcx}}$ \\
\hline & B & $5.13 \pm 0.18^{\mathrm{aX}}$ & $5.86 \pm 0.40^{\mathrm{bx}}$ & $5.44 \pm 0.08^{\mathrm{bx}}$ & $6.05 \pm 0.18^{\mathrm{abX}}$ \\
\hline & $\mathrm{C}$ & $4.88 \pm 0.18^{\mathrm{ax}}$ & $4.72 \pm 0.40^{\mathrm{ax}}$ & $4.32 \pm 0.09^{\mathrm{ax}}$ & $5.05 \pm 0.18^{\mathrm{ax}}$ \\
\hline & $\mathrm{K}$ & $8.00 \pm 0.24^{\mathrm{cX}}$ & $7.79 \pm 0.11^{\mathrm{cX}}$ & $7.32 \pm 0.26^{\mathrm{dX}}$ & $7.25 \pm 0.59^{c x}$ \\
\hline
\end{tabular}

a, b, c, dMeans in the same column with different superscripts significantly differ $(\mathrm{P}<0.05)$

$\mathrm{X}, \mathrm{Y}$ Means in the same row with different superscripts among kefir samples significantly differ $(\mathrm{P}<0.05)$

SD: Standard deviation of means

A: $80 \%$ cow milk - $20 \%$ oat milk kefir; B: $60 \%$ cow milk - $40 \%$ oat milk kefir; C: $40 \%$ cow milk - 60 \% oat milk kefir; K: Control sample (100\% cow milk kefir)

\section{Microbiological characteristics}

The viable cell counts of lactococci, lactobacilli and yeasts determined during storage period are presented in Table 7. The viable lactococci count for sample A and for control sample remained relatively constant until the end of storage, whereas the other two samples $(B, C)$ had variable results $(P<0.05)$. Although there were significant differences between samples for viable counts of lactococci during the first week of storage $(\mathrm{P}<0.05)$, these differences weren't significant and never declined less than 6.0 $\log \mathrm{cfu} / \mathrm{mL}$ afterwards.

As it can be seen from Table 7, storage period effected only the viable lactobacilli counts of sample A and $\mathrm{C}(\mathrm{P}<0.05)$ while the control sample had the lowest count $(6.03 \log \mathrm{cfu} / \mathrm{mL})$ throughout the storage. The differences between samples were found significant $(\mathrm{P}<0.05)$ at all periods except at the $21^{\text {st }}$ day of storage. Essentially, kefir containing $60 \%$ oat milk (C) attracted attention among the samples by having the highest count of both, lactococci and lac- tobacilli, at all periods. Such data may be related to the ability of these bacteria to utilize maltose, which is the main fermentable carbohydrate present in the oat milk.

Yeasts play an important role during kefir fermentation because of end-products like ethanol and carbon dioxide, which give the kefir drink its unique taste (Kesenkaş et al., 2011b). The viable counts of yeasts remained in the range of 4.73-5.36 log cfu/ $\mathrm{mL}$ in all samples until the end of a storage period (Table 7). Although insignificant differences were noted between samples at the first day of storage, significant differences were found during the rest $(\mathrm{P}<0.05)$. Thereat the control sample showed higher yeast counts (5.36 log cfu/mL) except at the $21^{\text {st }}$ day. Thus, storage period apparently affected yeast counts only in samples B and C $(\mathrm{P}<0.05)$. Such data might indicate that the increased lactose amount positively affected the viable cell count of yeasts in kefir samples. 
Table 7. Changes in the viable counts of Lactococcus spp., Lactobacillus spp. and yeasts in kefir samples during storage for 21 days $(\log \mathrm{cfu} / \mathrm{mL}, \mathrm{n}=3, \pm \mathrm{SD})$

\begin{tabular}{|c|c|c|c|c|c|}
\hline & Samples & Day 1 & Day 7 & Day 14 & Day 21 \\
\hline \multirow{4}{*}{ Lactococcus spp. } & A & $6.22 \pm 0.04^{c}$ & $6.31 \pm 0.02^{\mathrm{bc}}$ & $6.05 \pm 0.16$ & $6.06 \pm 0.21$ \\
\hline & B & $5.91 \pm 0.04^{\mathrm{ax}}$ & $6.21 \pm 0.08^{\mathrm{abY}}$ & $6.16 \pm 0.08^{Y}$ & $6.28 \pm 0.06^{Y}$ \\
\hline & $\mathrm{C}$ & $6.62 \pm 0.20^{\mathrm{dz}}$ & $6.47 \pm 0.00^{\mathrm{cYZ}}$ & $6.26 \pm 0.02^{x}$ & $6.35 \pm 0.07^{X Y}$ \\
\hline & $\mathrm{K}$ & $6.05 \pm 0.01^{b}$ & $6.03 \pm 0.02^{\mathrm{a}}$ & $6.02 \pm 0.03$ & $6.04 \pm 0.11$ \\
\hline \multirow{4}{*}{ Lactobacillus spp. } & A & $6.23 \pm 0.00^{\mathrm{abXY}}$ & $6.38 \pm 0.12^{\mathrm{bY}}$ & $6.15 \pm 0.02^{\mathrm{ax}}$ & $6.10 \pm 0.03^{x}$ \\
\hline & B & $6.33 \pm 0.06^{\mathrm{b}}$ & $6.10 \pm 0.08^{\mathrm{a}}$ & $6.24 \pm 0.17^{\mathrm{a}}$ & $6.17 \pm 0.18$ \\
\hline & $\mathrm{C}$ & $6.74 \pm 0.02^{\mathrm{cW}}$ & $6.43 \pm 0.02^{\mathrm{bY}}$ & $6.53 \pm 0.01^{\mathrm{bZ}}$ & $6.36 \pm 0.01^{\mathrm{x}}$ \\
\hline & K & $6.10 \pm 0.13^{\mathrm{a}}$ & $6.03 \pm 0.02^{\mathrm{a}}$ & $6.16 \pm 0.01^{\mathrm{a}}$ & $6.19 \pm 0.00$ \\
\hline \multirow{4}{*}{ Yeasts } & A & $5.29 \pm 0.10$ & $5.31 \pm 0.06^{\mathrm{bc}}$ & $5.18 \pm 0.01^{\mathrm{bc}}$ & $5.20 \pm 0.01^{\mathrm{b}}$ \\
\hline & B & $5.35 \pm 0.01^{Y}$ & $5.18 \pm 0.03^{\mathrm{bY}}$ & $5.07 \pm 0.16^{\mathrm{bXY}}$ & $4.81 \pm 0.15^{\mathrm{aX}}$ \\
\hline & $\mathrm{C}$ & $5.16 \pm 0.16^{Y}$ & $4.92 \pm 0.09^{\mathrm{aXY}}$ & $4.82 \pm 0.01^{\mathrm{aX}}$ & $4.73 \pm 0.01^{\mathrm{ax}}$ \\
\hline & $\mathrm{K}$ & $5.25 \pm 0.16$ & $5.36 \pm 0.05^{c}$ & $5.36 \pm 0.06^{c}$ & $5.20 \pm 0.04^{\mathrm{b}}$ \\
\hline
\end{tabular}

$\mathrm{a}, \mathrm{b}, \mathrm{c}, \mathrm{d}$ Means in the same column with different superscripts significantly differ $(\mathrm{P}<0.05)$

$\mathrm{X}, \mathrm{Y}, \mathrm{Z}, \mathrm{W}$ Means in the same row with different superscripts among kefir samples significantly differ $(\mathrm{P}<0.05)$

SD: Standard deviation of means

A: $80 \%$ cow milk - $20 \%$ oat milk kefir; B: $60 \%$ cow milk - $40 \%$ oat milk kefir; C: $40 \%$ cow milk - $60 \%$ oat milk kefir; K: Control sample (100\% cow milk kefir)

\section{Conclusion}

The importance of vegetal based fermented products as probiotic carriers increases day by day. At this point, oat based kefir products developed in this study was a product with an odour, taste and consistency that were found to be acceptable at maximum addition of $20 \%$ oat milk. Thus it can be concluded that there was no need to mask eventually occurring off flavours below that ratio. Fermentation with kefir grains led to enough acid development and viable counts similar to the control sample. This study demonstrates a possibility to produce an acceptable and value added kefir based on oat milk that can be alternative to similar market products.

\section{Inovativan pristup: kefir na bazi mješavine kravljeg i zobenog mlijeka}

\section{Sažetak}

Cilj ovog istraživanja bio je utvrditi mogućnost proizvodnje kefira iz mješavine kravljeg i zobenog mlijeka. Stoga su proizvedeni uzorci kefira s 20, 40 i
60 \% zobenog mlijeka. Tijekom 21 dana skladištenja na hladnom ispitivan je utjecaj različitih omjera zobenog i kravljeg mlijeka na fizikalna, reološka, mikrobiološka i senzorska svojstva proizvedenih uzoraka kefira. Povećanje udjela zobenog mlijeka uzrokovalo je povećanje sinereze, smanjenje prividne viskoznosti te smanjenje proteolitičke aktivnosti u uzorcima kefira. Osim toga, povećanje udjela zobenog mlijeka rezultiralo je snižavanjem $\mathrm{pH}$ vrijednosti u uzrocima kefira. Statistička analiza pokazala je da se proizvedeni uzorci razlikuju u broju živih stanica laktokoka i laktobacila, s tim da je najveći broj utvrđen u uzroku s najvećim udjelom zobenog mlijeka. Kontrolni uzorak (bez zobenog mlijeka) sadržavao je povećan broj plijesni tijekom cijelog razdoblja čuvanja. Krajnji proizvod s udjelom od $20 \%$ zobenog mlijeka i bez dodatka aroma pokazao se najprihvatljivijim prilikom senzorske ocjene od strane panela. Dobiveni rezultati mogu poslužiti u daljnjem razvoju proizvodnje kefira na bazi mješavine kravljeg i zobenog mlijeka.

Ključne riječi: kefir, zobeno mlijeko, senzorska analiza, reologija, mikrobiologija 


\section{References}

1. AOAC, (2000): Association of Official Analysis Chemists, Official methods of analysis. Vol II, $21^{\text {th }}$ edn. AOAC : Arlington,V.A. Secs.33.2.11 .

2. Bekers, M., Marauska, M., Laukevics, J., Grube, M., Vigants, A., Karklina, D., Skudra, L., Viesturs, U. (2001): Oats and Fat-Free Milk Based Functional Food Product, Food Biotechnology 15 (1), 1-12. doi: 10.1081/FBT-100103890

3. Bodyfelt, F.W., Tobias, J., Trout, G.M. (1988): The sensory evaluation of dairy products, AVI Publ. Westport, CT, 598.

4. Cirak, M.Y. (2009): Functional Dairy Products and Probiotics in Infectious Diseases. In: Yildiz, F. (Ed.), Development and Manufacture of Yogurt and Other Functional Dairy Products. CRC Press 395-417. doi: 10.1201/9781420082081-c14

5. Dinç, A. (2008): Kefirin bazı mikrobiyolojik ve kimyasal özelliklerinin belirlenmesi. A.Ü. Sağlık Bilimleri Enstitüsü Besin Hijyeni ve Teknolojisi Anabilim Dalı. Yükseklisans Tezi, Ankara.

6. Donkor, D.N., Nilmini, S.L.I, Stolic, P., Vasiljeviç, T., Shah, N.P. (2007): Survival and activity of selected probiotic organisms in set type yoghurt during cold storage, International Dairy Journal 17, 657-665. doi: 10.1016/j.idairyj.2006.08.006

7. Ertekin, B., Seydim, Z.B.G. (2010): Effect of fat replacers on kefir quality, Journal of the Science of Food and Agriculture 90 (4), 543-548. doi: 10.1002/jsfa.3855

8. Fernandez-Garcia, E., McGregor, J.U., Traylor, S. (1998): The Addition of Oat Fiber and Natural Alternative Sweeteners in the Manufacture of Plain Yogurt, Journal of Dairy Science 81, 655-6631. doi: 10.3168/jds.S0022-0302(98)75620-6

9. Garrote, G.L., Abraham, A.G., De Antoni, G.L. (2001): Chemical and microbiological characterization of kefir grains, Journal of Dairy Research 68, 639-652. doi: 10.1017/S0022029901005210

10. Gronnevik, H., Marit, F., Naruhus, J.A. (2011): Microbiological and chemical properties of Norwegian kefir during storage, International Dairy Journal 1, 1-6. doi: 10.1016/j.idairyj.2011.01.001

11. Guzel-Seydim, Z.B., Kok-Tas, T., Greene, A.K., Seydim, A.C. (2011): Functional Properties of Kefir, Critical Reviews in Food Science and Nutrition 51 (3), 261-268. doi: 10.1080/10408390903579029

12. Irigoyen, A., Arana, I., Castiella, M., Tarre, P., Ibanez, F.C. (2004): Microbiological, physicochemical, and sensory characteristics of kefir during storage, Food Chemistry 90, 613-620. doi: 10.1016/j.foodchem.2004.04.021

13. Jelicic, I., Bozanic, R., Tratnik, J. (2008). Whey based beverages, a new generation of dairy products, Mljekarstvo 58 (3), 257-274.
14. Karagül-Yüceer, Y., Avsar, Y.K. (2009): Health Attributes of Yogurt and Functional Dairy Products. In: Yildiz, F. (Ed.), Development and Manufacture of Yogurt and Other Functional Dairy Products. CRC Press 307-315. doi: 10.1201/9781420082081-c10

15. Kesenkaş, H., Dinkçi, N., Seçkin, K., Kınık, Ö., Gönç, S. (201 1a): Antioxidant Properties of Kefir Produced from Different Cow and Soy Milk Mixtures, Journal of Agricultural Sciences 17 (3), 253-259.

16. Kesenkaş, H., Dinkçi, N., Seçkin, K., Kınık, Ö., Gönç, S., Ergönül, PG., Kavas, G. (2011b): Physicochemical, Microbiological and Sensory Characteristics of Soymilk Kefir, African Journal of Microbiology Research 5 (22), 3737-3746. doi: 10.5897/ajmr1 1.579

17. Kılıç, S., Uysal, H.R., Akbulut, N., Kavas, G., Kesenkaş, H. (1999): Chemical, microbiological and sensory changes in ripening kefirs produced from starters and grains, Ziraat Fakültesi Dergisi 36, 111-118.

18. Lambo, A.M., Öste, R., Nyman, M.E.G.L. (2005): Dietary fibre in fermented oat and barley $\beta$-glucan rich concentrates, Food Chemistry 89, 283-293. doi: 10.1016/j.foodchem.2004.02.035

19. Martensson, O., Öste, R., Holst, O., (2000): Lactic acid bacteria in an Oat-based Non-dairy Milk Substitute: Fermentation Characteristics and Exopolysaccharide Formation, Food Science and Technology 33, 525-530. doi: 10.1006/fstl.2000.0718

20. Martensson, O., Andersson, C., Andersson, K., Öste, R., Holst, O. (2001): Formulation of an oat-based fermented product and its comparison with yoghurt, Journal of the Science of Food and Agriculture 81, 1314-1321. doi: 10.1002/jsfa.947

21. Mejri, W., Sahli, S.B. (2014): Formulation of non-fat yogurt wit $\beta$-glucan from spent brewer's yeast, Journal of Hygienic Engineering and Design 8, 163-173.

22. Muir, D.D., Tamime, A.Y., Wszolek, M. (1999): Comparison of the sensory profiles of kefir, buttermilk and yogurt, International Journal of Dairy Technology 52 (4), 129-134. doi: 10.1111/j.1471-0307.1999.tb02854.x

23. Oysun, G. (2001): Süt ve Ürünlerinde Analiz Yöntemleri, Ege Üniv. Zir. Fak. Yay. No: 504, Ege Üniv. Zir. Fak. Ofset Atelyesi, Bornova, İzmir, Yürkiye, S: 306.

24. Öner, Z., Karahan, A.G., Çakmakç1, L. (2010): Effects of different milk types and starter cultures on kefir, Gıda 35 (3), 177-182.

25. Paraskevopolou, I., Athanasiadis, G., Blekas, A.A., Koutinas, M., Kanellaki, M., Kiosseoglou, V. (2003): Influence of polysaccharide addition on stability of a cheese whey kefir- milk mixture, Food hydrocolloids 17, 615-620. doi: 10.1016/S0268-005X(02)00122-4

26. Pogacic, T., Sinko, S., Zamberlin, S., Samarzija, D. (2013): Microbiota of kefir grains, Mljekarstvo 63 (1), 3-14.

27. Purnomo, H., Müslimin, L.D. (2012). Chemical characteristics of pasteurized goat milk and goat milk kefir prepared using different amount of Indonisian kefir grain and inactivation time, International Food Research journal 19, 791-794. 
28. Renner, E. (1993): Milchpraktikum Skriptum zu den Übungen, Justus Liebig Universität, Gießen, Germany.

29. Soccol, C.R., Vandenberghe, L.P.S.V., Spier, M.R., Medeiros, A.B.P., Yamaguishi, C.T., Lindner, J.D., Pandey, A., Soccol, V.T. (1997): The Potential of Probiotics: A Review, Food Technology and Biotechnology 48 (4), 413434.

30. Stepaniak, L., Fetlinski, A. (2002): Kefir, Encyclopedia of Dairy Science, 1049-1055, USA Academic Press, Maryland Heights.

31. Tratnik, L., Bozanic, R., Herceg, Z., Drgalic, I. (2006): The quality of plain and supplemented kefir from goat's and cow's milk, International Journal of Dairy Technology 59 (1), 40-46. doi: 10.1111/j.1471-0307.2006.00236.x
32. Turkish Codex, Standard for Fermented Milks (2001): TGK, Fermente Sütler Tebliği http://www.kkgm.gov.tr/ TGK/Tebliğ 2001-21html.

33. Wiszolek, M., Tamime, A.Y., Muir, D.D., Barcley, M.N.I. (2001). Properties of kefir made in Scothland and Poland using bovine, caprine and ovine milk with different starter culture, LWT 34, 251-261. doi: $10.1006 /$ fstl.2001.0773 